SRNL-STI-2013-00588

Rev. 0

\title{
REVIEW OF CLEANING SOLUTIONS FOR USE ON COMPONENTS OF THE 9975 SHIPPING PACKAGE
}

\author{
W. L. Daugherty \\ Savannah River National Laboratory \\ Materials Science \& Technology \\ Publication Date: September 2013
}

Savannah River Nuclear Solutions

Savannah River Site

Aiken, SC 29808

This document was prepared in conjunction with work accomplished under

Contract No. DE-AC09-08SR22470 with the U.S. Department of Energy. 
SRNL-STI-2013-00588

Rev. 0

\section{DISCLAIMER}

This work was prepared under an agreement with and funded by the U.S. Government. Neither the U. S. Government or its employees, nor any of its contractors, subcontractors or their employees, makes any express or implied: 1 . warranty or assumes any legal liability for the accuracy, completeness, or for the use or results of such use of any information, product, or process disclosed; or 2. representation that such use or results of such use would not infringe privately owned rights; or 3. endorsement or recommendation of any specifically identified commercial product, process, or service. Any views and opinions of authors expressed in this work do not necessarily state or reflect those of the United States Government, or its contractors, or subcontractors. 


\title{
REVIEW OF CLEANING SOLUTIONS FOR USE ON COMPONENTS OF THE 9975 SHIPPING PACKAGE
}

\author{
APPROVALS: \\ W. L. Daugherty \\ Author, Materials Science and Technology \\ B. J. Wiersma \\ Technical Review, Materials Science and Technology \\ D. R. Leduc \\ Savannah River Packaging Technology \\ G. T. Chandler \\ Manager, Materials App \& Process Tech
}

\section{REVIEWS:}

K. A. Dunn

Pu Surveillance Program Lead, Materials Science and Technology 
SRNL-STI-2013-00588

Rev. 0

\section{Revision Log}

$\begin{array}{lll}\text { Document No. } & \text { SRNL-STI-2013-00588 Rev. No. } 0\end{array}$

Document Title Review of Cleaning Solutions for Use on Components of the 9975 Shipping Package

Rev. \# Page \# Description of Revision Date

$\begin{array}{lll}0 & \text { all Original document 9/30/2013 }\end{array}$ 
Rev. 0

\section{Review of Cleaning Solutions for Use on Components of the 9975 Shipping Package}

\section{Summary}

Several candidate cleaning products have been reviewed for use as a disinfectant on 9975 shipping package components which contain or have contacted mold. Following review of the compatibility of these products with each component, ammonia (ammonium hydroxide diluted to $1.5 \mathrm{wt} \%$ concentration) appears compatible with all package components that it might contact. Each of the other candidate products is incompatible with one or more package components. Accordingly, ammonia is recommended for this purpose. It is further recommended that all components which are disinfected be subsequently rinsed with di-ionized or distilled water.

\section{Introduction}

The 9975 shipping package is used extensively on the Savannah River Site and throughout the DOE complex for the transport and storage of nuclear materials. A small number of these packages have been identified with elevated moisture levels at least locally within the fiberboard assembly. Among other effects, this can lead to the growth of mold in the fiberboard and on any adjacent surfaces. Before such a package is re-certified, any non-conforming conditions are corrected. This might include actions such as replacing the fiberboard assembly and disinfecting the adjacent components (Figure 1).

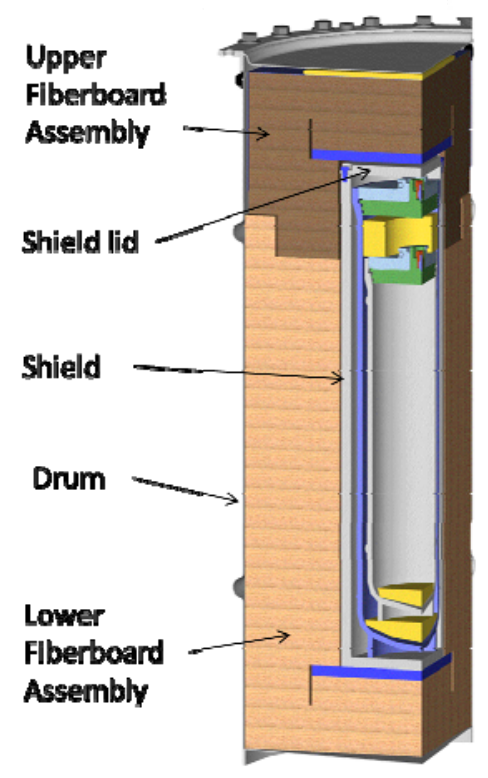

Figure 1. Cutaway view of 9975 shipping package showing components of interest

Several candidate cleaning solutions have been identified by Industrial Hygiene for use as disinfectants (see Table 1). These include specific commercial products and generic chemical compounds. Any of the products would be sprayed on the components, allowed to sit for about an hour, and then wiped off. This report provides a review of these candidate products for compatibility with the 9975 package components. 
Rev. 0

Table 1. Candidate products for disinfectant use

\begin{tabular}{|l|l|l|}
\hline Product & Comments & Reference \\
\hline Spray Nine multi-purpose cleaner & Mfg by ITW Permatex & 1 \\
\hline Formula 409 all purpose cleaner & Mfg by The Chlorox Company & 1 \\
\hline Bleach & 1 cup bleach per gallon of water & 2 \\
\hline Borax & 1 cup borax per gallon of water & 2 \\
\hline Vinegar & Use without dilution & 2 \\
\hline Ammonia & $50 \%$ clear (household) ammonia, 50\% water & 2 \\
\hline Hydrogen peroxide & Use without dilution (3\%) & 2 \\
\hline
\end{tabular}

\section{$\underline{\text { Evaluation Approach }}$}

This discussion addresses a range of scenarios in which mold has developed on one or more components of the 9975 package. Typically, this would be expected as a result of elevated moisture levels within the fiberboard assembly. Such moisture levels could result from water intrusion or from re-distribution of moisture already within the fiberboard due to a thermal gradient. Regardless of the source, movement of water through the fiberboard can leach and concentrate chlorides existing within the fiberboard. Any effort to eliminate mold on package components should also consider the presence of these compounds.

It is assumed that a fiberboard assembly that requires treatment for mold will not be re-used. However, the remaining package components that could have contacted mold (drum, shield, shield lid and bolts) should generally be acceptable for re-use, although treatment with disinfectant may be appropriate. There are several scenarios to be considered in evaluating the suitability of the candidate products, as follows:

- Will application of the product to the component cause direct, immediate degradation?

- $\quad$ Will any product residue remain on the component and cause long-term degradation?

- $\quad$ Will any product residue remain on the component, migrate to another component and cause long-term degradation to that component?

With regards to the third scenario, it has been shown that moisture within the fiberboard assembly will migrate preferentially to cooler regions when an internal heat load creates a thermal gradient within the fiberboard [3]. It is reasonable to expect that after a heat load is removed, the moisture will tend to migrate back to a more uniform distribution. With each migration, any soluble constituents in or around the fiberboard may be leached out and concentrated elsewhere.

The effects of any residue from cleaning / disinfecting activities must be considered. This includes residue from the cleaning product(s), residual chlorides already within the package, and potential reaction products between the cleaning product(s) and residual chlorides and other compounds present. In addition, the potential reaction between any residual compounds and a replacement fiberboard assembly should be considered, along with the impact of reaction products on adjacent components. 
Rev. 0

\section{$\underline{\text { Discussion }}$}

The two commercial products each contain a number of ingredients, as identified in Table 2. For Spray Nine, two active ingredients are listed on the label and two hazardous ingredients are listed in the MSDS. The remaining ingredients are proprietary and were not readily identified. All ingredients of Formula 409 are listed on the company web site, although concentrations of ingredients were only found for the hazardous ingredients listed in the MSDS. With these two ingredients listed second and third (after water), it is reasonable that the remaining ingredients are at lower concentrations $(\sim 0.3 \%$ or less). The remaining candidate products are relatively simple compounds, as noted in Table 2.

Table 2. Chemical makeup of candidate products

\begin{tabular}{|c|c|c|}
\hline Product & Ingredients / Chemistry & Concentration \\
\hline \multirow[t]{5}{*}{ Spray nine } & $\begin{array}{l}\text { alkyl C12-C18 dimethyl benzyl } \\
\text { ammonium chloride }\end{array}$ & $0.15 \mathrm{wt} \%$ \\
\hline & $\begin{array}{l}\text { alkyl C12-C14 dimethyl } \\
\text { ethylbenzyl ammonium chloride }\end{array}$ & $0.15 \mathrm{wt} \%$ \\
\hline & ethoxylated C9-C11 alcohols & $1-5 \mathrm{wt} \%$ \\
\hline & $\begin{array}{l}\text { dipropylene glycol monobutyl } \\
\text { ether }\end{array}$ & $1-5 \mathrm{wt} \%$ \\
\hline & Proprietary ingredients & \\
\hline \multirow[t]{8}{*}{ Formula 409} & water & \\
\hline & lauramine oxide & $0.5-1.5 \mathrm{wt} \%$ \\
\hline & $\begin{array}{l}\text { alkyl C12-16 dimethylbenzyl } \\
\text { ammonium chloride }\end{array}$ & $0.2-0.4 \mathrm{wt} \%$ \\
\hline & $\begin{array}{l}\text { dimethicone / silica / PEG } \\
\text { distearate antifoam }\end{array}$ & \\
\hline & ethanolamine & \\
\hline & fragrance & \\
\hline & $\begin{array}{l}\text { Liquitint } \AA \text { bright yellow dye, } \\
\text { Liquitint } \AA \text { blue HP dye }\end{array}$ & \\
\hline & tetrapotassium EDTA & \\
\hline Bleach & Sodium hypochlorite & 6 wt\% (Chlorox bleach), diluted to 0.55 wt\%* \\
\hline Borax & $\begin{array}{l}\text { Sodium tetraborate decahydrate, } \\
\mathrm{Na}_{2} \mathrm{~B}_{4} \mathrm{O}_{7} \cdot 10 \mathrm{H}_{2} \mathrm{O}\end{array}$ & 1 cup borax per gallon water, $\sim 10$ wt $\%$ \\
\hline Vinegar & Acetic acid, $\mathrm{CH}_{3} \mathrm{COOH}$ & $\sim 8$ vol\%, no dilution \\
\hline Ammonia & Ammonium hydroxide, $\mathrm{NH}_{4} \mathrm{OH}$ & $3 \mathrm{wt} \%$ (typical concentration) diluted to $1.5 \mathrm{wt} \%$ \\
\hline $\begin{array}{l}\text { Hydrogen } \\
\text { peroxide }\end{array}$ & $\mathrm{H}_{2} \mathrm{O}_{2}$ & $3 \mathrm{wt} \%$ (typical concentration), no dilution \\
\hline
\end{tabular}

* Reference 2 specifies dilution of 1 cup bleach per gallon of water (1 to 16 ratio) and also indicates a ratio of about 1 to 10 . The higher concentration is assumed in this report. 
Rev. 0

Evaluation of the components warrants consideration of their location, ease of cleaning off any chemical residue, and consequences of chemical attack. For instance:

- $\quad$ Most surfaces of the 304L stainless steel drum are easily accessed for disinfecting and rinsing. However, there is a tight crevice around the bottom edge which cannot be wiped clean, in which any remaining chemical will concentrate and may be re-dissolved by migrating moisture.

- $\quad$ The lead shield may contain an adherent layer of corrosion product (lead carbonate) which may preclude complete wiping or rinsing of disinfectant from the surface. In addition, a newer shield (with an exterior stainless steel sleeve) will be difficult to rinse unless the sleeve can be removed. On the other hand, these features would also decrease the likelihood of any trapped chemical residue migrating to other components.

- $\quad$ The aluminum shield lid is easily handled, and has no tight crevices or other inaccessible regions to preclude thorough wiping / rinsing. In addition, since it does not have to maintain a seal on the shield, it can sustain a significant degree of degradation without compromising its function.

- $\quad$ The stainless steel shield lid bolts are easily removed for wiping / rinsing.

- $\quad$ Upon return to service and placing a heat load inside the package, the thermal gradient will tend to drive moisture within the fiberboard away from the shield and shield lid and towards the drum sides and bottom. Moisture would not likely migrate back toward the shield and shield lid until after the package is emptied.

The possibility that any residue will undergo chemical reaction with the fiberboard should be considered. If such reaction occurs, the reaction product(s) may be corrosive to adjacent components.

Review of the candidate products identified only one - ammonia - that is suitable for use on all of the affected package components. Each of the other products is incompatible with one or more components. Specifically:

Chloride containing products (Spray Nine, Formula 409 and bleach) will likely leave residue, especially within the drum crevice and behind a shield sleeve, and can lead to chloride stress corrosion cracking of the stainless steel components (drum, shield sleeve, and shield lid bolts) [4]. Chlorox bleach contains 5.7 wt\% chlorides [5], and would be diluted (per above) to $\sim 5200 \mathrm{ppm}$ chlorides. The other products each contain several thousand ppm chlorides, and are not diluted before use.

- $\quad$ Ammonium chloride (Spray Nine, Formula 409), bleach and borax solutions produce high corrosion rates ( $>50$ mils/yr) in aluminum [6].

- $\quad$ Both vinegar and hydrogen peroxide produce high corrosion rates ( $>50$ mils/yr) in lead [6]. In fact, the lead corrosion typically observed in service has been attributed to acetic acid (vinegar) off-gassing from the fiberboard assembly [7].

The following information was identified specific to household ammonia (ammonium hydroxide). Since household ammonia has a nominal concentration of $3 \mathrm{wt} \%$, it would be diluted with an equal part water. It is recommended that distilled or de-ionized water be used for this purpose. Water from other sources (including potable water) could contain halogens (chlorides, fluorides) which are undesirable for stainless steel contact, or could be slightly acidic which would (at least partially) neutralize the ammonia. 
Rev. 0

- $\quad$ Lead experiences negligible corrosion in ammonium hydroxide and is "satisfactory for use in the liquid or gas phases at virtually all temperatures and concentrations" [8].

- $\quad$ Corrosion rates of aluminum in ammonium hydroxide range from negligible to 10 mils/yr, depending on $\mathrm{pH}$. The higher corrosion rates occur in the $\mathrm{pH}$ range of $\sim 10-13$ [9]. The corrosion rate can be influenced by the presence of other chemicals which alter the $\mathrm{pH}$ [10].

- $\quad$ Stainless steels show good corrosion resistance at all concentrations up to the boiling point of ammonium hydroxide [8].

Based on the above, the primary concern from ammonium hydroxide is to the aluminum shield lid. This concern would last only during the cleaning process, since ammonia and water are both volatile and will evaporate. In addition, if chlorides have been leached from the fiberboard and deposited on other components, the formation of ammonium chloride should be considered. This salt would be left behind after the liquids evaporate, and present a corrosion concern for the drum, shield sleeve and lid and the bearing plates of the replacement fiberboard assembly.

Careful rinsing of each component after disinfecting would significantly reduce the amount of any residue, including ammonium chloride. Such residue, in combination with moisture, would present a corrosion concern for the stainless steel and aluminum components. The replacement fiberboard assembly would typically contain close to $10 \mathrm{wt} \%$ moisture, which will re-distribute when a heat load is placed in the package. Initially, moisture will move preferentially towards the drum. Upon unloading, moisture will tend to migrate back toward the internal components (shield liner(s), shield lid and bolts, and fiberboard bearing plates).

It is recommended that all components be rinsed with de-ionized or distilled water after contact with ammonium hydroxide. Specific regions likely to trap ammonium hydroxide include the drum crevice and under the stainless steel sleeve of newer shields. While these two components are not susceptible to corrosion from ammonium hydroxide, they are susceptible to corrosion from ammonium chloride. It is also a general good practice to minimize such residue left on any component.

Since the fiberboard assembly can produce acetic acid fumes (especially a newer assembly in which the glue is not fully cured), the possibility of interaction between ammonium hydroxide and acetic acid is considered. The reaction product would be ammonium acetate, and Reference 6 identifies good corrosion resistance of aluminum and stainless steel to this product. Since acetic acid is known to cause corrosion of lead, and is the basis for commercial production of lead carbonate, it is unlikely that ammonium acetate would lead to degradation of the shield beyond that due to acetic acid. Therefore, this reaction product is not expected to have a net negative impact on the shield.

\section{References}

[1] Electronic mail message “Chlorox 409” from Sherolyn Bishop to Donald Trapp, February 28, 2013 
Rev. 0

[2] Electronic mail message "solution for killing mold” from Sherolyn Bishop to Donald Trapp, September 4, 2013

[3] SRNL-STI-2011-00113, “Model 9975 Life Extension Package 1 - Final Report”, W. L. Daugherty, March 2011

[4] WSRC-TM-95-1, SRS Engineering Standards Manual, Standard 05952, "Required Practices to Minimize Chloride Induced Stress Corrosion Cracking of Austenitic Stainless Steel”, Rev. 5, May 26, 2009

[5] Chlorox service bulletin, http://www.clorox.com/pdf/5813-50_service-bulletins.pdf, The Chlorox Company

[6] Corrosion Resistance Tables, $3^{\text {rd }}$ edition, P. A. Schweitzer, Marcel Dekker, Inc., New York, 1991

[7] WSRC-MS-2005-00406, “Shipping Package 9975-02234 Lead Shield Corrosion Product”, W. L. Daugherty, July 5, 2005

[8] Handbook of Corrosion Data, $2^{\text {nd }}$ edition, B. D. Craig and D. S. Anderson, ASM International 1995, pp 27, 148 - 150

[9] Metals Handbook, $9^{\text {th }}$ edition, Volume 2 Properties and Selection: Nonferrous Alloys and Pure Metals, ASM, Metals Park, Ohio, 1979, p 234

[10] Corrosion of Aluminum and Aluminum Alloys, J. R. Davis, Ed., ASM, Metals Park, Ohio, 1999, pp. 38-39 
Rev. 0

CC: J. S. Bellamy, 730-A

S. G. Bishop, 773-A

G. T. Chandler, 773-A

W. L. Daugherty, 773-A

K. A. Dunn, 773-41A

T. W. Griffin, 705-K

T. J. Grim, 105-K

E. R. Hackney, 705-K

D. R. Leduc, 730-A

J. W. McEvoy, 707-42B

D. J. Trapp, 723-A

B. J. Wiersma, 773-A

K. E. Zeigler, 773-41A

Document Control 